European Science Foundation expands 'additional' activities

THE European Science Foundation, which over five years has established the role of 'stimulant' for European cooperation in basic research, is increasing its emphasis on 'additional', directly funded research. Approximately half of ESF's 10 million FF expenditure is now devoted to such work, and the proportion is increasing.

One example is a proposal for work in taxonomy, which the ESF believes is neglected in Europe - to the extent that assessment of environmental impacts (of $\mathrm{SO}_{2}$ for example) are hindered. A 'European Floristic, Taxonomic, and Biosystematic Documentation System' should thus be established, and the work required would become an 'additional activity' of the ESF. This means that the 46 national research councils which are members of the ESF will be asked if they would like to contribute to the activity as an addition to their membership subscription to the Foundation.

Lord Flowers, in his presidential introduction to the 1979 annual report (to be published shortly) says: "It is through the additional activities that our work as a foundation will stand or fall"'. But he adds "we are conscious that each new activity adds to the financial burden of those of our members who participate in them".

For some additional activities, however, funds have been made available from outside sources such as the Leverhulme Trust and the Commission of the European Communities (which is supporting a study on the mobility and employment of scientists).

"Participation in the additional activities represents on the part of our member organisations a conscious and deliberate intention to give a certain priority to research which is conducted at a European level"' writes Flowers.

The increasing importance of additional activities, which was hardly foreseen when the ESF was set up, may however lead to some difficulties among its members. They will be increasingly invited to fund projects controlled not from their own offices but from the ESF, testing their commitment to Europe. Thus, says the report, "money from an organisation in country A can and will be used to pay a scientist coming from country $\mathrm{B}$, and possibly working in country C'. Some members have already set up a new category in their budgets for 'European cooperation' to allow for this, says the report.

Another indication for the future of the Foundation was the agreement at this year's annual general meeting, held in Strasbourg earlier this month, that tentative approaches should be made to

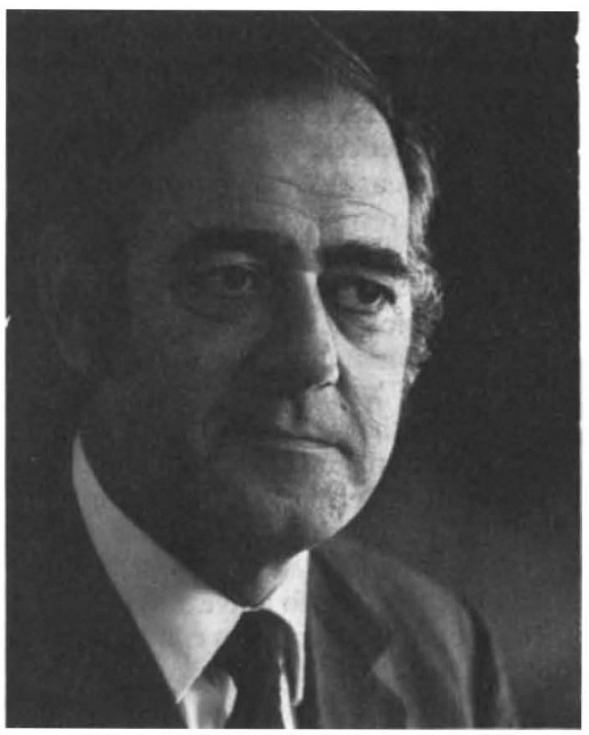

Lord Flowers: promoting European activities

Soviet and East European scientific bodies to enquire if they might participate in some of the ESF's activities - without becoming official members. Lord Flowers will visit Moscow next year with this in mind.

Turkey's Scientific and Technical Research Council also joined the ESF this year, and Finland, announced it will become a full member. Robert Walgate

\section{European synchrotron radiation facility brings governments together}

IN AN unprecedented move, the European Science Foundation is to approach governments - albeit gingerly - to discuss the construction of a $\$ 120$ million European Synchrotron Radiation Facility.

Officially, the ESF will have nothing to do with governments, and preserves its independence jealously. Unofficially, the retiring secretary-general of ESF, Dr F Schneider, will in his retirement be convening an intergovernmental committee with the object of making the ESRF a reality. Thus the committee will strictly not be a part of ESF activities, although it is ESF-inspired.

Dr Schneider, who is retiring this year to be succeeded as ESF secretary-general by Belgian lawyer John Goormagtigh, complains in an unsigned introduction to this year's annual report, that the lack of access to governments hampers the Foundation. The ESF's influence compared unfavourably with that of the National Academy of Sciences in the US, says the article. "A project proposed by the NAS is brought to the government for decision. The National Aeronautics and Space Administration's space science budget is decided in one place, not fifteen capital cities."

The report recommends a new role for the ESF: "In cases where concerted action is needed, a new machinery enabling the
Foundation to approach governments in the name of all its members [national research councils] and to act for them ought to be developed'.

The ESF has prepared the case for the facility in two booklets produced by Yves Farge, director of the Laboratoire pour l'Utilisation des Rayonnments Electromagnétique (LURE), Orsay, and collaborators. The booklets are titled "ESRF: the feasibility study" (pp67) and "ESRF: the scientific case"' (pp173) (May 1979) available from $\mathrm{H}$ Schmied, European Science Foundation, 1 quai Lezay-Marnésia, F-67000 Strasbourg, France.

\section{European Space Agency "crippled space science in Europe"' says ESF report}

WHEN the European Space Agency was established, funds for scientific research were confined to no more than $12-15 \%$ of the whole budget, to make room for an applications programme and the development of Ariane (ESA's own launcher, due for test flight in December) and Spacelab. "It is now apparent that this was wrong" says an independent report just published by the European Science Foundation. The chosen level of funding "seriously crippled space science in Europe', leaving European space scientists with only one sixth of the resources available to US scientists.

"Launches of ESA satellites are so infrequent" claims the report "that each hardware-building institute in Europe has approximately two chances in ten years" of participating in an ESA payload. "This is utterly inadequate, because the programme is so small that new talent is not likely to be attracted". Some 1500-2000 scientists in the countries of ESF members are presently using the results of space investigations, the report estimates.

Financial pressures have also limited ESA's collaborations with the National Aeronautics and Space Administration; ESA's contribution to the space telescope, for example, is only $15 \%$. Europe should aim to match the US and the USSR in space science, says the report. An annual ESA launch rate of one satellite fully instrumented by European groups, and "additional spacelab flight opportunities" will be required to keep European groups above "the critical threshold of efficiency",

The report recommends that ESA increase its mandatory scientific budget. But this requires unanimous approval by all ESA member states, and is therefore unlikely. Optional programmes could augment the mandatory budget, however, because they allow funding to be more flexible, says the report. "Space Science in Europe" (pp66) available from $\mathrm{H}$ Schmied, ESF, 1 quai Lezay-Marnésia, F-6700Strasbourg, France. 